\title{
Balogh Mihály
}

\section{VARGA DOMOKOS, AZ ABSZOLÚT PEDAGÓGUS ${ }^{1}$}

DOI: https://doi.org/10.32558/abszolut.2021.23

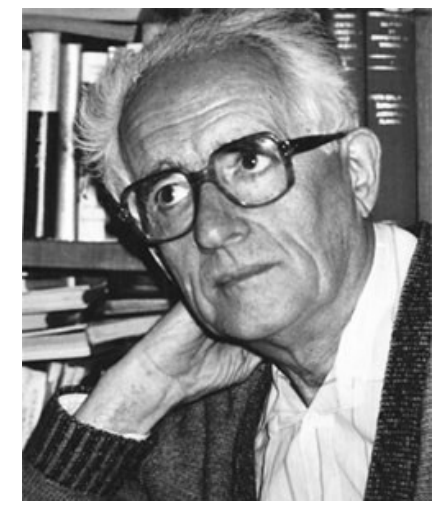

Varga Domokos (1922-2002)

\section{Mentegetőzés és problémafölvetés}

Tisztelt jelenvalók! Mindenekelőtt köszönöm a megtisztelő fölkérést. A magam mentségére mondom el, hogy nem voltam, nem vagyok elméleti pedagógus, sem neveléstörténész, sőt még irodalomtörténész sem. Tanár és könyvtáros voltam, ma is az vagyok - nyugdíjasként. De szabadidőmet és szabad szellemi kapacitásomat évtizedek óta leköti szűkebb pátriám, Kunszentmiklós múltjának megismerése, közreadása, így a Kunszentmiklóskutató címkét örömmel fogadom. Ebben a minőségemben kerülhettem ugyanis kapcsolatba a Vargha családdal, és kerültem negyven éve személyes kapcsolatba, majd barátságba Vargha Balázzsal és Domokossal. Amiről alább beszélni fogok, az sokkal inkább az imént vázoltak hozadéka, mint hézagos pedagógiai tudásomé.

Miután tisztáztam, mit keresek én ma itt, a tárgyra térve fölteszem magunknak az alapkérdést: mit keres ma itt Varga Domokos? Pedagógus volt-e ő vajon? S ha az volt, vajon azok közé az abszolút pedagógusok közé

\footnotetext{
1 A Magyar Pedagógiai Társaság Kiss Árpád Műhelyének 2013. december 10-i múhelybeszélgetésén elhangzott vitaindító előadás szerkesztett változata Varga Domokosról (1922-2002). A tanulmány teljesebb változata megjelent az Iskolakultúra 2014/3. számában.
} 
tartozott-e, akik „minősített formában részesítették előnyben a tanítást teljes vagy részleges életpályaként saját tudományos, múvészi vagy irodalmi tevékenységükkel szemben vagy azokat kiegészítendő”. Kérdéseinkre Varga Domokos életében és mûveiben keresünk választ. Az életmú tömör áttekintése után egy pillantást vetünk az alkotó gyökereire, a család, a szülőhely, az iskolák, s a mesterek által az életműhöz hozzáadott értékekre. Ezek révén kerülhetünk közelebb a felnőtt ember életútjának megértéséhez, az alkotói oeuvre értelmezéséhez.

\section{Pillanatfölvétel}

Varga Domokos Kunszentmiklóson született 1922-ben, Vargha Tamás református lelkész és Magay Mária hét gyermeke közül a negyedikként. Szülőhelyén érettségizett 1940-ben, majd Sopronban szerzett erdőmérnöki diplomát. Az ötvenes években rádiós és újságíró, az 1956-os forradalom után két év börtönbüntetést szenvedett. A rabságban vált íróvá: 1964-től sorra jelentek meg a könyvei. A hetvenes évek elejétôl szabadúszó íróként dolgozott, miközben feleségével, Stolte Magdával hét gyermeket neveltek föl.

Félszáznál több múvének legfontosabb témái a családi élet és a rejtelmes gyermeki világ; szinte minden írása tanít és nevel, és szinte minden írása a szentmiklósi gyermekkor világában gyökerezik. Kitüntetései között nagyra becsülte az alma matertől kapott Pro Schola emlékérmet, meg a szülőváros díszpolgári címét. Életmûvét 2002. március 15-én Kossuth-díjjal ismerték el. Négy hónappal nyolcvanadik születésnapja előtt, 2002. május 12-én hunyt el. A Farkasréti temetőben nyugszik. Az életművét lezáró Vig játék - végjaték utolsó lapjain Goethe halhatatlan sorainak átköltésével búcsúzik az élettől:

Az ormokon fenn
Semmi nes₹:
A lomb között sem
Sejdites\%,
Csak halk. fuvalmat,
Az erdön egy madár se szól.
Várj, nyúgoszol
Te is mabolnap.

\section{Gyökerek, iskolák, mesterek}

Egy kétszáz éves magyar értelmiségi család címmel közölte Varga Domokossal készült interjúját Albert Zsuzsa a Forrás-ban. Itt is, mit a vele készült más beszélgetésekben, az író szívesen, részletesen szólt fölmenőiről. 
Tanítók, tanárok, papok, jogászok, orvosok, tudós irodalmárok, szépírók költők nemzedékei növesztették, terebélyesítették a „Vargák” családfáját.

Anyai ágon a felvilágosodás idején múködnek Debrecenben a Budai testvérek: a tudós professzor, Ézsaiás, meg a lexikonszerkesztő Ferenc. Apai ágon kortárs testvérpár, a Bécsi Magyar Kurírt szerkesztő Márton József és a pápai kollégiumot fölvirágoztató Márton István biztosítanak erős indítást a litterátus nemzedéksornak. Ők négyen ugyan oldalági fölmenők, de ugyancsak apai ágon, egy-két nemzedékkel később a Bolyaiakkal barátkozó enyedi professzor, a matematikus idősebb Szász Károly ükapaként, majd a fia, a pap, tanár, költő, műfordító, politikus ifjabb Szász Károly dédapaként, már egyenes ági fölmenők. A nagymama, Szász Póla ereiben is csörgedezett némi költő́i véna, a statisztikus, államtitkár nagyapa Vargha Gyula viszont több kötetes költő, legjobb versei a magyar impresszionista líra közvetlen előzményei.

A Pestról falura került református papnak, Vargha Tamásnak és a szentmiklósi Magay Máriának is öt-öt testvére volt. A családban csak Sapának és Mamámnak becézett szülők pedig már hét gyereket neveltek a szentmiklósi parókián. A hét közül a középső Domokos, a család nyelvhasználatában csak Dombi - egy nővérrel és két báttyal, meg egy húggal és két öccsel.

$\mathrm{Az}$ íróvá érett Varga Domokosnak az írásait átszövő egyik kulcsfogalma a család lesz majd. A másik a gyermekkor színtere, Kunszentmiklós. Nyilván nem véletlen, hogy szinte nincs írása ezek nélkül. Két könyve már a címében is hordozza ezt a két fogalmat, mintegy megelólegezvén kitüntetett szerepeket. Amilyen természetes módon volt a Varga-gyerekeknek Szentmiklós a világ közepe, épp oly természetes módon volt a világ közepének közepe a Varga-család.

Az író több interjúban szólt szüleiről, testvéreiről, az ő külön kis gyermek-köztársaságukról, amely nyaranta a bő tucatnyi unokatestvérrel kibővülve uralta a parókia tágas udvarát, kertjét. Családi játékaik fő forrása és irányítója Sapa volt, aki szent áhítattal vallotta a nemzet költói lángelméjének Arany Jánost, így az Arany-idézetek kitalálása mindennapos feladatuk volt a gyerekeknek. Sapa másik erőssége a logika, a matematika lévén, különféle észjátékokkal is erős gondolkodásra késztette gyermekeit. „Boldogult Balázs bátyámnak van néhány játékos könyve, ezeknek jó részét az apám játékaiból vette.” - mondja egy helyütt Varga Domokos. Ám ez a megállapítás vonatkoztatható Tamás bátyjára, illetve az ô munkáira is.

A „Vargák” a húszas évek derekától egy évtizeden át koptatták azt elemi iskolai padokat. Varga Domokos úgy emlékezett ezekre az évekre, 
hogy az elemi iskola ugyan csak írni, olvasni, számolni tanította meg a nebulókat, de azt egyrészt igen alaposan, másrészt viszont az iskolai penzumok bőven mellett hagyott időt nekik a világ saját jogú és módszerű megismerésére.

Éva 1928-ban iratkozott be a szentmiklósi református gimnáziumba. Amikor ő - Jóború Magda osztálytársaként - 1936-ban kitűnő érettségit tett, abban a tanévben a hétből öten már a gimnázium tanulói voltak. Tamás következett, majd jött „Sándor Balázs”, Domokos és Ida. Amikor pedig a legifjabb fiú, Dénes érettségizett, akkor élte meg az iskola utolsó előtti „egyházi” esztendejét. A következőnyáron, 1948-ban államosították. Akkor Jóború Magda már ismert kommunista politikus, országgyűlési képviselő, a három idősebb fiú pedig a magyar kulturális közélet sűrűjében tevékenykedett.

Kis híján más iskolákban kellett tanulniuk a Vargha gyerekeknek, mert 1924-ben egy miniszteri rendelet majdnem megszüntette a szentmiklósi gimnáziumot, s csak helyi összefogással és erős lobbizással sikerült megmenteni. Trianon utáni menekültek, meg „19-es” feketelistások jöttek tanítani, köztük néhány valóban kitűnő, eredeti koponya is.

„Tanárainkat vettük sorba baráti beszélgetés kö̈ben: Csipszit, Kappant, Stikit, Samut, Misát, Leposát, Szepit és a többieket. Véleményünk hajszálra egybevágott: egyik bülyébb, mint a másik. Egyszerüen nem értettünk, bogyan sikerült egyetlen iskolába ennyi nevetséges, furcsa figurát összeszalajtani. 'Válogatott állatsereglet' - mondtam én ki zengö hangomon. S még büszke is voltam rá, hogy ilyen találóan fogalmaz̦tam meg a lényeget." Mielőtt igazat adhatnánk hajdani kamaszként a hajdani kamasznak, az író így folytatja vallomását a Kamaszkrónikában a félistenek gyarló voltáról: „Pedig ma nem a kegyelet, hanem az igazságérzet mondatja velem: szinte érthetetlen, hogyan sikerïlt abban az idóben e kis vidéki gimnázium tanári karába annyi kitünö koponyát, annyi eredeti egyéniséget egybegyüjteni."

Az iskola helyi frontembere a matematika - fizika szakos. Zsámboki Lajos volt, a cserkész „parnok”, mindenféle közösségi kezdeményezés szervezője és mozgatója. Országos hírnevet a tornatanár, idős Miklóssy János garantált, az általa fölkészített diákok másfél évtizeden át uralták a honi diáksportot. Atlétái és úszói is végigverték a magyar gimnáziumok hasonló csapatait. Európai (el)ismertséget szerzett a klasszika filológia jeles művelője, az iskola Platón fordító „szórakozott professzora”, Dr. Kövendi Dénes. És volt a rajztanár-festőművész Gál Sándor, aki a kortárs képzőművészet modern irányzatait és technikáit tanította diákjainak.

A korábbi Eötvös kollégista, a történelem - földrajz szakos ifjú Miklóssy János a saját zseniális ötletét megvalósítva, nagy forgalmú nyilvános könyvtárrá 
szervezte át a tanári könyvtárt. El lehetett érni a Nyugatot és a Szép Szót, a Magyar Élet és a Cserépfalvi kiadványait, a friss szociográfiákat, s a népi irók könyveit. A gyüjtemény a nagyobb diákoknak is nyitva állt.

Az író a Kamaškerónikában mind az öt tanárt bemutatja, elismeri tanári kvalitásaikat. Azt a Kövendit is magasra emeli, akit a közvélekedés lenyűgöző tudása ellenére „rossz tanárként” könyvelt el, mert nem tudott rendet tartani, a fegyelmezés akkor szokásos eszközeit nem alkalmazta. De azok a diákok, akik kíváncsiságból vagy szánalomból alkalmanként mégis odafigyeltek rá, olyasmiket hallhattak, tanulhattak tőle, amiket senki mástól a tanári karból.

Mind a három Vargha fiút tanították az itt sorolt szentmiklósi tanárok. A fiúk nem jeleskedtek a cserkészetcsapatban, a sportkörben és a zenekörben, viszont otthonosak az egyházi diákszervezetekben és az önképzőkörben meg a művészeti rajzban. Az 1935/36-os tanévben az önképzőkör „humán” fődíját Jóború Magda nyerte, Jókai irói módja címú munkájával, a természettudományos fő́dijat pedig a hetedikes Varga Tamás, a Minden mozog címú természetfilozófiai értekezéssel. Tamás hetedikben önképzőköri titkár, nyolcadikban ifjúsági elnök volt. Hatodikosként első dijat nyert a Körben Balázs, Karrier című novellájával, majd ezt az eredményt elérte hetedikben is, de nyolcadikban már nem ,jegyzik" az önképzőköri szereplését.

Domokos csak a Bethlen Gábor Körben volt aktív. Nyolcadikban ő a Kör elnöke, beszédet mond október 31-én, a reformáció ünnepén. Végig kitűnő volt, ifjú Kövendi Dénessel ketten érettségiztek kitűnőre az osztályból 1940-ben. ${ }^{2}$

A család tüdőbajtól tartott a nyurga, görbe tartású ifjúnál, ezért tanári álmait föladva Sopronba került erdőmérnök hallgatónak. Ott tanulta meg a fegyelmezett szellemi munkavégzést, a matematikai alapú, logikus gondolkodást, a lényegkeresés és a pontosság igényét.

Első írásai is a főiskola folyóiratában jelentek meg.

\section{Indulás}

A háború után a friss diplomás erdőmérnök a szakmájában kezdett dolgozni Debrecenben, majd egy év után Pestre került, ahol az 1946 nyarán megalakult Magyar Cserkészfiúk Szövetsége elnökeként a híres professzor, Karácsony Sándor Varga Domokosra bízta a Cserkészfiúk címú lap szerkesztését. A lap munkatársai közt voltak más Karácsony-tanítványok is,

\footnotetext{
2 A Vargha-testvérek középiskolai tanulmányairól lásd a Kunszentmiklósi Református Gimnázium aktuális évkönyveit az 1930-as, 1940-es évekből. Varga Domokosnak ifjú Kövendi Dénes, a későbbi „karácsonyista” könyvtáros mellett osztálytársa volt többek között Szalay László, a neves biofizikus, szegedi egyetemi tanár, valamint a sokszoros válogatott, olimpiai bronzérmes és Európa-bajnok atléta, Csányi György.
} 
többször előfordult a cikkek alatt Hegyi Füstös István, Kulin György, Radványi Ottó, Szűcs Sándor, Tárkány Szűcs Ernő neve.

Maga az ifjú szerkesztő névvel, nagyobb terjedelmú cikket keveset írt a lapba, de az 1948. évfolyam január-februári számában övé a vezércikk, Cserkészet és iskola címmel, és a márciusi, ünnepi szám vezércikkét is ő jegyzete - Petôfi meg mi címmel. De az április - májusi szám címlapját már Rákosi Mátyás képe tölti be, az 1948. júniusi számmal pedig meg is szűnik a lap, előre vetítve a magyar cserkészmozgalom hamarosan bekövetkező fölszámolását.

A középiskolások diákszervezete a Magyar Diákok Nemzeti Szövetsége, az MDNSZ volt. Ennek orgánumaként 1947 márciusában új ifjúsági hetilap indult Március Tizenötödike címen. Egy idő után Vargha Domokos ennek a lapnak a szerkesztésébe is bekapcsolódott. 1947 őszétől egy karácsonyistákból álló kis kunszentmiklósi csoport uralja a lapfelületet. Állandó szerző a három Varga mellett Kövendi Dénes és későbbi jeles muzeológus, Dankó Imre is.

A legmozgékonyabb közülük Balázs: nagy valószínűséggel ő húzódik meg a két keresztnevéből álló Sándor Balázs név mögött - kisebb kulturális tárgyú írások szerzőjeként. Saját nevén a régi debreceni kollégiumról, meg Mindnyájunk Attilájáról ír nagyobb cikket. Tamás A mi kis világunk címmel ír az 1948. március 15-i számban természettudományos ismeretterjesztő cikket, amelyben képzeletbeli csillagközi utazás segítségével magyarázza a táguló világegyetemet, s a relativitáselméletet.

Domokosnak jó részt leköthette az energiáját a Cserkészfiúk szerkesztése, így ritkábban bukkant föl a lap hasábjain. 1948 január 2-án egész oldalas írást vállal Rózsa Sándor 48-a címmel, majd az 1948. április elsejei számban iskolai tárgyú cikkel jelentkezik: Hisz̧en ez érdekes címmel a tanulás sajátos módszerét mutatja be. A módszer lényege diáktársunk „felfedezése”, a közös érdeklődésre építő közös tanulás, amely magával hozza a közös élmény izgalmát.

1948 nyarától, a politikai fordulat után kiszorulnak a lapból a karácsonyisták. Noha júniusban „Sándor Balázs” még beszámol a Derkovits kiállításról, Domokos pedig két könyvismertetéssel jelentkezik, ezek azonban már nyúlfarknyi írások, majd a Vargák is eltűnnek a lapból.

\section{Megbicsaklástól kiteljesedésig}

Varga Domokos 1948 és 1958 közötti évtizedét méltán tarthatjuk az író pokoljárásának. Hangzatos címkével élve a Szabad Néptől a Gyűjtőfogházig tartott ez a korszaka.1948-ban megnősült, és míg sorra születtek a gyerekek, 
hatan a tíz év alatt, ôt magával sodorta a politika. Gyorsan váltják egymást csalódások és remények: dolgozik az MDP vezetô lapjánál, a Szabad Népnél, a Falurádióban, munkatársa lesz az Irodalmi Újságnak, szocialista termelési jelentéseket és élmunkás portrékat ír, fölbukkan 1956-ban a Petőfi Kör vitáin, megéli a reményekkel teli október végét, november közepén szerepet vállal az újpesti munkásgyúlésen. Ezután bebörtönzik, végül pedig, miután a nehéz évtizedben messzire sodródott irodalomtól, pedagógiától, a két év börtön, a távoli család sajgó hiánya íróvá avatja, kiszakítja belőle a Kutyafuilüek történetét.

A hatvanas évek az erdészkedésé, a kényszerú írói hallgatásé, majd az újbóli megszólalásé. Ekkor találja meg a további pályáját végigkísérő alaptémát és alaphangot: az Ipiapacstól és a Kutyafuiluiektól $A$ népek kenyerég sorjázó munkáiban a pedagógiai próza szépirodalmi, esszészerű vagy ismeretterjesztő változatai szólalnak meg. Ez hang a továbbiakban is alapmotívuma marad, ez jellemzi a következő két évtized, a hetvenes-nyolcvanas évek pedagógiai tematikájú bő tucatnyi művét is. Csak jelzésszerűen emelem ki most közülük a saját kamaszkorát vallomásos hangon fölidézó Kamaškkónikét, az elidegenedő, elárvult világban a testvért a legnagyobb ajándéknak véló Kölyökekóstolgatót, meg a Tisztelt családom...-at, amelynek egyes darabjait az özvegy, Stolte Magda ,józanésszel megírt pedagógiai művek"-nek minősít - nem föltétlenül elismerő hangon.

Mindenféle értelemben a kiteljesedés időszaka Varga Domokos számára élete utolsó alkotó évtizede. A rendszerváltást követő kilencvenes években a különböző közéleti feladatvállalásai mellett a nevelés iránti tartós elkötelezettségét jelzi a mélyen átélt „,nemzet szolgálómestere” szerep erősödése az életmúben, a kisdiákok számára írt szerkesztett olvasókönyvekben és a határon túli nagyobb diákok számára írt történelemkönyvekben elsősorban.

\section{Varga Domokos pedagógiai természetrajza}

Fiatalabb korában olykor még a gyakorlati pedagógia is megkísértette Varga Domokost. A soproni evangélikus líceumban különórákon tanította a finn nyelvet - maga is diákként. Debrecenben 1945-46-ban a dolgozók gimnáziumban természetrajzot tanított. Egy év múlva Pesten a MADISZ-os fiataloknak tartott irodalmi szemináriumokat és tanított népdalokat, de még a börtönévek után is, erdőmérnöki munkája mellett egy ideig erdész szakmunkástanulók számtan és mértan tanára volt. Nagyjából ennyi Varga Domokos direkt, többé-kevésbé formalizált pedagógiai gyakorlata.

A benne szorult tanárságról többször is vallott a különböző, vele készült beszélgetések során:

„Valóban tanár szerettem volna lenni, de rossz tanár lettem volna, a tanterv ellen folyton lázadó, a szabadon szárnyaló gyermekekiváncsiságnak könnyen engedó, elkalandozó. 
Ezért jobb is tán, hogy könyvek.kel nyitogatom a gyerekek eszét, szemét, s így élem ki a belém rekedt pedagógiai ambiciókat."

Nem lett a tanárságból semmi, mint ahogy az erdőmérnökségből se sok, írja le másutt, de sebaj: „engem világéletemben csak a pedagógia érdekelt igazán”. S ha tanár - papírok nélkül - nem is lehetett, de írni írhatott. Így születhettek meg a pedagógiai jellegú könyvei.

„... hiszem és vallom, hogy én inkább vagyok pedagógus, mint iró,... Elsösorban mindig pedagógiai szándékok, törekvések fütöttek, amikor egyik vagy másik... könyvembez. bozzákezdtem."

Egyszerre és természetes módon volt képes szülő és családpedagógus lenni, s akár a gyerekei tanulását is megszervezni. Különleges pedagógiai eseményei voltak ennek a szervező munkának a Varga-családban az érettségire készülő gyerekek fölkészítését célzó, szakértő vendégek bevonásával megszervezett „családi szabadegyetemek”. A saját gyerekeik mellé az ő barátaikból is verbuválódott hallgatóságot áthatotta az „önkéntes vállalás” boldog tudata. Ajándékként fogták föl azt a tudást, amit az előadóktól kaptak. Ezek a legfontosabb szakmai előzményei az író gyermek- és ifjúsági ismeretterjesztő munkáinak.

Pedagógiai alapelveit, gondolkodását illetően természetesen Varga Domokos is Karácsony Sándor köpönyegéből bújt ki. Pedagógiai felfogását, a nevelésről, tanításról vallott nézeteit át meg átszövi a Karácsony Sándor-i pedagógia, írásaiban a nehéz évtizedekben is búvópatakként bukkantak elő szeretett mestere tanításai. Ennek a tanításnak fontos kulcsfogalmai Varga Domokos munkásságában többek között, a szeretetre és empátiára építő pedagógia hatékonysága, az egyoldalúan ismeretközlő, a világot tantárgyakra trancsírozó, a nagy egészet megragadni képtelen, a gyerek előzetes ismereteit negligáló tanítási rendszer fogyatékos volta, a (nagy)család belső, kohéziós nevelőereje stb.

Szemléletnek a leglényegesebb elemeit a Bozóky Éva által készített, $V$ allomás és tanitás címú interjúban kísérelte meg összefoglalni az író.

A szülő és az iskola dolga is az, hogy legyen képes a megismerés folyamatában a természetes gyermeki kíváncsiságot felkelteni és ébren tartani, ennek érdekében pedig elérni, hogy élmény és tudás minél inkább összetartozzon a világot megismerő gyermekben. Mert „a világhoz való érželmi kötödés az az alapélmény, amely azután a tudásszomja legföbb szitója lehet".

$\mathrm{Az}$ iskola sajnos alig épít a gyerekek „hozott” tapasztalataira, ismereteire, sem az anyanyelvi szintjére, ill. annak természetes fejlődőképességére. Ezek helyett kap a gyerek az iskolában egy „álnyelven”, előre gyártott nyelvi formulákban megfogalmazott „tudománypárlatot”, így többnyire tőle idegen dolgok szajkózására kényszerül - „szájába nem illő mondatokkal”. Mindezek 
helyett: a diákot segíteni kellene a fogalmak tisztázásában, az összefüggések megértésében, a kérdések föltevésében, a kételyek kimondásában, egyszóval az önálló gondolkodásban. „Annyit ér az iskola, amennyit ezen a téren elér.”

Egy másik interjúban Karácsony Sándorra névvel is hivatkozva egészítette ki az előbbieket:

„Nem szabad az iskolában, a tananyagban a világot részelere szabdalni, az egészet kell látni, láttatni. A kisgyerek még természetes módon él benne a maga teljességében, ismeri fel és meg annak összefüggéseit. De majd a rossz iskola leszoktatja erról a képességéröl. Az iskolának a gyerek fejében tovább kellene fejlesztenie, erösitenie azt a rendszert, ,amely a tudást szervessé és maradandóvá teheti." Ki kellene épülnie a gyerek gondolkodásában egy térbeli, időbeli, logikai hálónak, „ahol mindig a már meglévó tudáshoz kapcsolódnak a dolgok, és nagyjából mindent el lehet helyezni, értelmét a többihez képest tisżtãnn?. (...) Ez az iskola, a pedagógus dolga is lenne, de az iskolának, a pedagógusnak ez nem mindig sikerül, mert az iskola mással próbálkozik. „Teljes rendszert viszont nem lehet szốröstül-böröstül átplántálni az egyik emberi fejböl a másikba."

A kisgyermekek, az iskolakezdők korosztálya furcsa, olykor gyötrő kettősségként éli meg a kényszerú átmenetet a már kiválóan múködő szóbeliségéből a még döcögő, primitívebb szintú írásbeliségbe, az írás-olvasás „tudományának” elsajátításakor a gyerekekben fölmerülő fogas kérdésekbe, hiányérzetbe. A ,gyermeknyelv" meg az ,iskolanyelv" értelemgyötro”, hiányérzetet generáló kettősségével szemben az alkalmas válaszokat a tanulók kérdéseire az ügyes tanító azzal oldhatja fel, hogy olvasásra, élményszerű olvasásra kapatja a gyereket.

Persze az sem mindegy, mit olvas a gyerek, s ez már a tankönyv szerzőjének felelőssége. A szövegválogatásban olyan irodalmi értékek élvezzenek elsőséget, amelyek által oldódni képes „az iskolán belüli és kívüli világ kettőssége”, hogy - Adyval szólva - minél inkább ,élet zengje be az iskolát”, s hogy ezzel együtt az élet is „derűs iskola” legyen. Mert a gyerekek sokfélék, s mindnek keresni kell a kulcsot az eszéhez-szivéhez...

Az irodalommal való találkozás, érzelmi összehangolódás elemi élményét semmi más nem pótolhatja, hangsúlyozza végül Varga Domokos, aki ezért annak örül leginkább, hogy több tanító panaszkodott már: a gyerekek „előre olvasnak..."

Hogy világosabb legyen, mire gondol az író a gyermeknyelv - iskolanyelv kettősségét fölemlegetve, egy gyerekkori élményét idézi föl. „Tiženkét-tizenhárom éves lehettem. IV. Béláról irtunk dolgozatot. Jómagam ezzel fejeztem be: 'Méltán nevezzüle Magyarország második megalapitójának.' Aztán újra elolvastam ez̦t az utolsó mondatot, s egyszerre nagyon távolinak, idegennek éreztem magamtól. Söt hazugnak, szégyenletesnek. Ezt a szót: méltán - élóbeszédben én soha nem használtam. Nem hallottam a családban sem, az. 
egész városban sem senkitól. Néztem, csak néztem, mit is irtam le, s valami undorféle jött fel a torkomon. S ez volt talán az a pillanat, amikor eldölt: egyszer még iró lehet belölem, annyira viszolygok a hamis, a hazug, a nem a saját lelkemböl fakadó szavaktól, megfogalmazásoktól.

Ma már le tudom irni - a maga helyén -, hogy méltán. Sok mindent le tudok irni, ami régen-gyerek-és ifjúkoromban - nem tartozott szó-és kifejezéskincsembez: Az öszinte stilus befogadásra és fejlödésre képes. Természetesen mindig összhangban a személyiség fejlödésével. De a hamis stílusra kényszerült gyerek stílusa úgy ,fejlódik", hogy megzavarodik. Föleg az. irott nyelve, de többé-kevésbé az élóbeszéde is. Altalános iskolánk felsö tagozatában már-már tömegesnek mutatkozó jelenség ez, mondhatnám, népbetegség, amely a felnött korra is kiható, tartós károsodást okoz:"

A nagycsalád életképessége, előnyei mellett érvelő író egyik kulcsmondata: „Hét gyereknek te parancsolsæ egy gyerek neked parancsol.” A kis, vagy csonka (nukleáris) családot többnyire a gyerek uralja. A mai gyerekek egyre többet kívánnak anyagiakban is, de törődésben nevelésben is, igénylik a közös játékot, az együtt nevetést, a család mint társaság pedig különleges nevelőnövelő erő. Sok egyke gyerek szomorú, keresné a testvéreit, de nem leli. Pedig fontos a testvér, mert egyszerre támasz és vetélytárs, és mindkettőre szükség is van a harmonikus nevelődéshez. A több testvér pedig még jobb ebből a szempontból. Ráadásul a köztudat szerint a családban a szülők nevelik a gyerekeket. Valójában: a családi közösség neveli - több-kevesebb sikerrel - a szülőket is, a gyerekeket is. A család tagjai szerencsés esetben egymásra hangolódnak, s termékeny érzelmi-szellemi-erkölcsi kapcsolatba lépnek. Még szerencsésebb esetben ez a termékeny kapcsolat a serdülőkor éveiben is kitart a szülők és a gyerekek között.

Varga Domokos „,családkönyveinek” olvasásakor lépten-nyomon abba a felismerésbe ütközünk, hogy miközben a szerző a maga tapasztalataiból levonja a maga tanulságait, rendre érzi és érzékelteti, hogy akár a családon kívüli világ hatásai, akár a család belsô mikrovilágának kapcsolatai sokkal bonyolultabbak és változatosabbak annál, hogysem a tapasztalatokból leszűrt tanulságok kőtáblába véshető nevelési axiómákká, általános érvényű tantételekké válhatnának.

A közösségi kontroll 19. századi kimúlását követően a nukleáris vagy csökött, csonka családok megjelenésével ez utóbbiak szerepe fölértékelődött, mert még ezek is jobbak, mint a semmilyen (nem létező) családok. Még akkor is igaz ez az állítás, ha ezeknek a családoknak egy részében sajnos már megjelenhet a „mérgező pedagógia”, vagyis a család - egyes tagjai révén - akár durván negatív szerepet is betölthet ma már a gyermek nevelődésében.

Szülők, magatokon kezdjétek gyermekeitek nevelését! - üzeni minden érdekeltnek Varga Domokos. „Ahhoz, hogy igazán nevelni tudjuk öket, az, kell, hogy ök is megneveljenek bennünket." 
Az író apa, nagyapa töprengései nem csupán a tapasztalatoktól a tanulságokig vezető út stációi: a megfogalmazott tanulságoktól az új tapasztalatokig terjedő intervallumot is kitöltik. „A drága jó szülók ...minden tóliuk telhetöt megcselekedhetnek. a gyerekeikért, többé-kevésbé még ak.kor is mindig bizonytalan marad a végeredmény. A nevelés már csak ilyen: vagy sikerül, vagy nem."

\section{Summa: abszolút pedagógus volt?}

Végső soron sem a scientia-, sem az ars paedagogica jelentéstartománya szerint, szorosan véve nem volt pedagógus Varga Domokos. Viszont maga volt, teljes személyiségével és szinte a teljes írói munkásságával a homo paedagogicus. A lényéből korláttalanul áradó nevelői furor a célközönséget illetően nem ismert korosztályi határokat. Kisóvodásoktól az aggastyánokig bárkit meg akart és meg is tudott szólítani, és mindenkihez volt is nevelő-tanító szava.

Kiss Endrének az édesapjáról, Kiss Árpádról mondott szavai Varga Domokosról is bízvást is elmondhatók: ,a szellem problémáival foglalkozó szabad ember..." volt, aki a múveivel a világegészből kiindulva világképet tanított és világlátásra nevelt - mindig népben-nemzetben gondolkodva.

Varga Domokos, az író, a művész, azt gondolom, valóban abszolút pedagógus volt. 